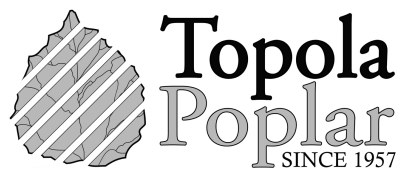

Original scientific paper

\title{
Variation of Leaf Water Potential and Leaf Gas Exchange Parameters of Seven Silver Linden (Tilia tomentosa Moench) Genotypes in Urban Environment
}

\author{
Lazar Kesić ${ }^{1, *}$, Vanja Vuksanović ${ }^{2}$, Velisav Karaklić ${ }^{1}$, Erna Vaštag ${ }^{2}$ \\ 1 University of Novi Sad, Institute of Lowland Forestry and Environment, Novi Sad, Serbia \\ 2 University of Novi Sad, Faculty of Agriculture, Novi Sad, Serbia
}

* Corresponding author: Lazar Kesić; E-mail: kesic.lazar@uns.ac.rs

Received: 30 Mar 2020; Revised: 3 Apr 2020; Accepted: 27 May 2020

\begin{abstract}
Differences between genotypes are considered to be the most important requisite for a resilient urban forest. Analyses of physiological traits, such as leaf water potential and leaf gas exchange could provide useful insight into the capacity of different species and genotypes to grow in harsh urban environments. In the present study, a variation of midday ( $\left.\Psi_{\mathrm{md}}\right)$ and predawn $\left(\Psi_{\mathrm{pd}}\right)$ leaf water potential, net photosynthesis $(\mathrm{A})$, rate of transpiration $(\mathrm{E})$, stomatal conductance $\left(\mathrm{g}_{\mathrm{s}}\right)$, and intercellular $\mathrm{CO}_{2}$ concentration $\left(\mathrm{C}_{\mathrm{i}}\right)$ of seven Silver linden genotypes (Tilia tomentosa Moench), planted in the urban environment in Novi Sad, were examined. Analysis of variance and LSD tests were used to show differences between studied silver linden genotypes. The results showed significant differences for all observed leaf gas exchange parameters (A, E, $\mathrm{g}_{\mathrm{s}}, \mathrm{C}_{\mathrm{i}}, \Psi_{\mathrm{pd}}$ and $\left.\Psi_{\mathrm{md}}\right)$ between genotypes. The results indicate better physiological performances of genotypes $\mathrm{T} 3$, in comparison to other observed genotypes under the prevailing environmental condition of the studied site in the urban environment.
\end{abstract}

Keywords: leaf water potential, leaf gas exchange, Silver linden, genotypic variation.

\section{Introduction}

Silver linden (Tilia tomentosa Moench) is a highly valued ornamental species native to South-East Europe and South-West Asia (Rushforth, 1999). In Europe, four Tilia species are distributed naturally: Caucasian linden $-T$. dasystyla (Stev.), silver linden $-T$. tomentosa (Moench.), small-leaved linden -T. cordata (Mill.) and large-leaved linden -T. platyphyllos (Scop.) (Filiz et al. 2015). Apart from their s natural abundance, especially Tilia cordata L. and T. tomentosa L. (Aničić et al. 2011), are commonly planted in parks and other categories of urban green spaces in the eastern Balkan region (Mauer and Tabel, 1995; Pawlikowski et al. 2010; Vaštag et al. 2018).

Differences between genotypes are essential for the ability of local populations to cope with varying environmental stresses, such as drought, heat wave, salinity stress, etc. (Possen et al. 2014). Plants were evidenced to endure these stress conditions with an array of morphological, physiological, anatomical adaptations (Vastag et al. 2020). In that term, higher physiological 
variation could lead to more exploitation of ecosystem niches and better productivity (Lindner et al., 2010). Indeed, high physiological variation among genotypes can enhance the resistance of stands to climate change (Roth et al. 2007). Having in mind the importance of physiological variation, a number of studies assessed between and within genotypic differences of leaf gas exchange parameters (Bhatt, 1990; Oren et al. 1996; Šircelj et al. 2007; Fini et al. 2009; Mozdzer and Zieman, 2010; Flood et al. 2011) and leaf water potential (Gaosegelwe and Kirkham, 1990; Bahrun et al. 2002; Klein, 2014; Reddy, 2019) of various species, including silver linden (Filiz et al. 2015).

The connection between physiological parameters has been a subject of many studies (Williams et al. 1994; Zufferey et al. 2000; Iandolino, 2004; Coupel-Ledru et al. 2014), highlighting the presence and the connection between them. Among all physiological parameters, the relationship between stomatal conductance $\left(g_{s}\right)$ and leaf water potential $(\Psi)$ was noted to have a key to the understanding of plants' function under the predicted climate changes (Silim et al. 2009; Jackson et al. 2015; Kostić et al. 2019). Namely, stomata were found to be highly sensitive to $\Psi$ (Gaosegelwe and Kirkham, 1990). Indeed, Bahrun et al. (2002) evidenced that $g_{s}$ can be reduced in the absence of a visible reduction of $\Psi$.

Many environmental factors, such as salinity, high temperature, etc., can affect leaf gas exchange (Lahr et al. 2018; Lintunen et al. 2019; Vastag et al. 2019) and leaf water potential (Gillner et al. 2017; Sjöman, et al. 2018; Li et al. 2020) in urbanised area. From all environmental factors occurring in urban settlements, urban trees are highly sensitive to water deficit which plays the main role in their survival (Fini et al. 2009). This issue becomes even complicated as it was shown that environmental factors might affect gene expression of morphological and physiological traits (Day et al. 2002; De Souza et al. 2008). The presence of genetic variation in photosynthesis could indicate that natural selection had favoured different genotypes depending on the local environment (van Rooijen et al. 2015).

Physiological parameters are closely related to changes in environmental conditions (Williams and Araujo, 2002) and it could be used for urban forest management in the future (Filiz et al., 2015). Therefore, for this purpose $\Psi_{\mathrm{md}}, \Psi_{\mathrm{pd}}, \mathrm{A}, \mathrm{E}, \mathrm{g}_{\mathrm{s}}$, and $\mathrm{C}_{\mathrm{i}}$ were used for research variation between silver linden genotypes. We studied leaf physiological variation of seven silver linden genotypes under the same urban environmental conditions. Our objectives were to: i) investigate variation in $\Psi$ between genotypes and to assess the difference between midday ( $\left.\Psi_{\mathrm{md}}\right)$ and dawn $\left(\Psi_{\mathrm{pd}}\right)$; ii) investigate variation in leaf gas exchange parameters between seven genotypes; and iii) assess the relationship between physiological parameters.

\section{Material and methods}

Seven genotypes of T. tomentosa planted in the street of Antona Čehova (N $45.24^{\circ} 75^{\prime} 07^{\prime \prime}$, E $19.83^{\circ} 11^{\prime} 38^{\prime \prime}$, elevation $80 \mathrm{~m}$ a.s.1.) in Novi Sad, Serbia, were used for the present study. In order to estimate the variability in physiological traits of Silver linden, measurement of leaf gas exchange and $\Psi$ were made on $30^{\text {th }}$ of August 2019. For these measurements, fully expanded leaves were chosen from the same orientation.

\subsection{Meteorological characteristics}

The air temperature, daily precipitations and soil moisture of the 2019 growing season (from $1^{\text {st }}$ of May until $4^{\text {th }}$ of September 2019) were recorded automatically. The air temperature was measured with a MINIKIN RTHi (EMS, Czech Republic), while daily precipitation was assessed with an automatic precipitation collector (Pronamic, Denmark). $\Psi_{\text {soil }}$ was measured with gypsum blocks (Delmhorst Inc., USA) at a soil depth of $50 \mathrm{~cm}$, by automatically recording every 30 minutes (Figure 1). During the measurement, the air temperature was $24.8^{\circ} \mathrm{C}$, soil moisture was $12.3 \%$ vol, and there was no precipitation. 


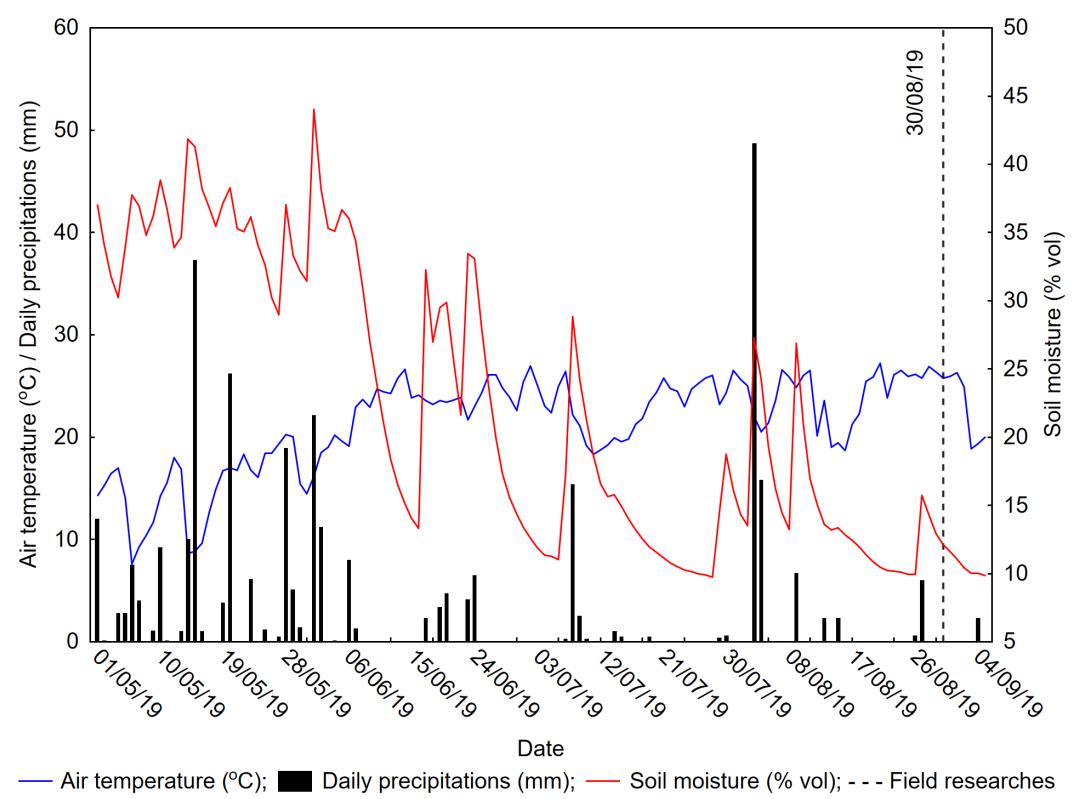

Figure 1. Air temperature $\left({ }^{\circ} \mathrm{C}\right)$, daily precipitations $(\mathrm{mm})$ and soil moisture $(\%$ vol) during growing season.

\subsection{Assessment of leaf gas exchange and leaf water potential}

$\Psi$ was measured with a Portable Plant Water Status Console (SAPS II, model 3155; Soil Moisture Equipment Corp., Santa Barbara, USA) before dawn $\left(\Psi_{\mathrm{pd}}[\mathrm{MPa}]\right)$ and at midday $\left(\Psi_{\mathrm{md}}\right.$ [MPa]). For each tree, three leaves were sampled and measurements were made immediately after excision. Measurements were made one fully expanded leaf.

Leaf gas exchange parameters (net photosynthesis $\left(\mathrm{A}\left[\mu \mathrm{mol} \mathrm{m}^{-2} \mathrm{~s}^{-1}\right]\right)$, rate of transpiration (E $\left.\left[\mathrm{mmol} \mathrm{m} \mathrm{m}^{-2} \mathrm{~s}^{-1}\right]\right)$, stomatal conductance $\left(\mathrm{g}_{\mathrm{s}}\left[\mathrm{mmol} \mathrm{m}^{-2} \mathrm{~s}^{-1}\right]\right)$, and intercellular $\mathrm{CO}_{2}$ concentration $\left(\mathrm{C}_{\mathrm{i}}\left[\mu \mathrm{mol} \mathrm{mol}{ }^{-1}\right]\right)$ were measured with a CIRAS-3 portable photosynthesis system (Amesbury, MA, USA) with red and blue LED light sources in a time scale between 9:00 AM and 11:00 AM. The measurements were recorded under photosynthetic active radiation (PAR) of $1000 \mu \mathrm{mol} \mathrm{m}-$ ${ }^{2} \mathrm{~s}^{-1}$, while humidity, air temperature and the concentration of $\mathrm{CO}_{2}$ were assessed during measurements. All measurements were made on one leaf per genotype and all parameters were recorded five times per leaf. All genotypes in this study had leaves fully developed, disease-free, and exposed to full sunlight in lower canopy ( 2 to $3 \mathrm{~m}$ above ground) (Herrick and Thomas, 1999; Tissue et al. 2001).

\subsection{Statistical analysis}

The statistical evaluation of the differences between the observed genotypes of Silver linden was made using ANOVA. The comparison of means was performed by applying the LSD test to determine the level of significance. Furthermore, the differences between the different genotypes were shown in the form of a diagram. All statistical analysis was performed in Statistica 13.3 (TIBCO Software, Inc.). 


\section{Results}

Based on one-way ANOVA, there were significant differences in $\Psi_{\mathrm{pd}}$ and $\Psi_{\mathrm{md}}$ among Silver linden genotypes. The lowest mean value of $\Psi_{\text {pd }}$ was observed for T4 $(-0.9 \pm 0.02 \mathrm{MPa})$, while T2 $(-0.5 \pm 0.48 \mathrm{MPa})$ had the highest mean value. Genotypes T1 $(-0.7 \pm 0.11 \mathrm{MPa}), \mathrm{T} 3(-0.72$ $\pm 0.06 \mathrm{MPa}), \mathrm{T} 5(-0.67 \pm 0.05 \mathrm{MPa}), \mathrm{T} 6(-0.58 \pm 0.02 \mathrm{MPa})$, and T7 $(-0.83 \pm 0.09 \mathrm{MPa})$ were ranked in descending order into different homogenous groups. Genotypes T3 (-1.9 $\pm 0.05 \mathrm{MPa}), \mathrm{T} 2(-1.9$ $\pm 0.01 \mathrm{MPa})$, and T6(-1.85 $\pm 0.05 \mathrm{MPa})$ had the lowest mean value of $\Psi_{\mathrm{md}}$, while genotype T5 ($1.65 \pm 0.1 \mathrm{MPa})$ had the highest (Figure 2). Genotypes T1 $(-1,7 \pm 0.05 \mathrm{MPa}), \mathrm{T} 4(-1.8 \pm 0.01 \mathrm{MPa})$, and T7 $(-1,7 \pm 0.1 \mathrm{MPa})$, were ranked in descending order into different homogenous groups. According to Mencuccini (2003) typical values of $\Psi$ range between -1 and $-2 \mathrm{MPa}$, down to -4 $\mathrm{MPa}$ in species occupying arid zones, and as low as $-10 \mathrm{MPa}$ in the most extreme cases (Tyree, 1997). Trees that have a low (more negative) $\Psi$ tend to maintain leaf gas exchange at lower soil water potentials ( $\left.\Psi_{\text {soil }}\right)$ and have an advantage where soil water deficits occur during the growth season (Mitchell et al. 2008; Blackman et al. 2010).
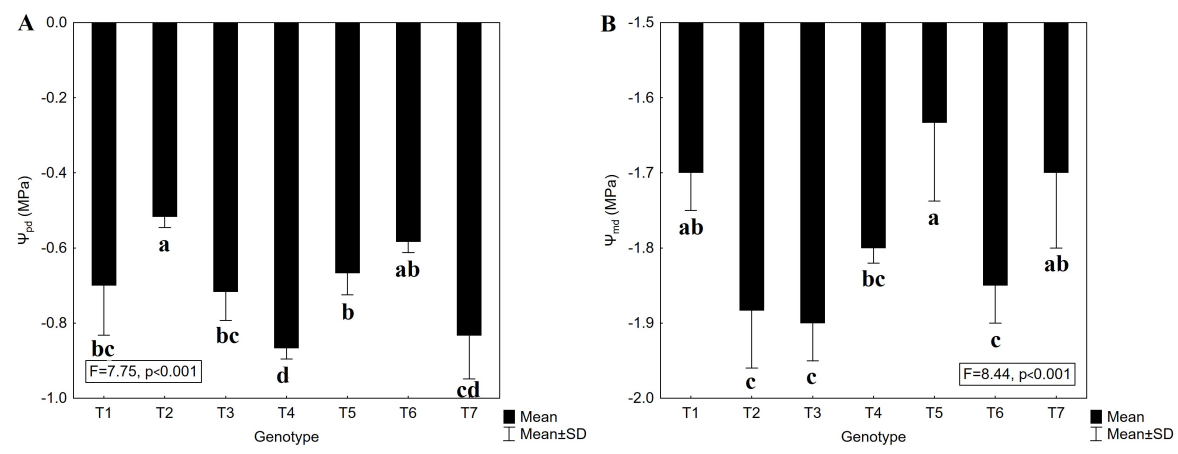

Figure 2. Leaf water potential for the observed silver linden genotypes. A) Pre-down leaf water potential $\left.\left(\Psi_{\mathrm{pd}}[\mathrm{MPa}]\right), \mathrm{B}\right)$ Midday leaf water potential $\left(\Psi_{\mathrm{md}}[\mathrm{MPa}]\right)$.

Regarding leaf gas exchange parameters, significant genotype differences were detected for all observed parameters $\left(\mathrm{A}, \mathrm{E}, \mathrm{g}_{\mathrm{s}}\right.$, and $\mathrm{C}_{\mathrm{i}}$ ). The highest $\mathrm{A}$ values were detected for genotype T3 $\left(5.78 \pm 0.38 \mu \mathrm{mol} \mathrm{m}{ }^{-2} \mathrm{~s}^{-1}\right)$, while genotype T1 was observed to have the lowest $(3.78 \pm 0.08 \mu \mathrm{mol}$ $\mathrm{m}^{-2} \mathrm{~s}^{-1}$ ) (Figure 3.A). There were no statistically significant differences between genotypes T2 (5.37 $\left.\pm 0.4 \mu \mathrm{mol} \mathrm{m}^{-2} \mathrm{~s}^{-1}\right)$ and T5 $\left(5.46 \pm 0.38 \mu \mathrm{mol} \mathrm{m}^{-2} \mathrm{~s}^{-1}\right)$ as well as between genotypes T1 (3.78 \pm 0.08 $\left.\mu \mathrm{mol} \mathrm{m} \mathrm{m}^{-2} \mathrm{~s}^{-1}\right)$ and T6 $\left(3.58 \pm 0.36 \mu \mathrm{mol} \mathrm{m} \mathrm{m}^{-2} \mathrm{~s}^{-1}\right)$ (Figure 3a). The highest E value was recorded for genotype T3 $\left(4.09 \pm 0.01 \mathrm{mmol} \mathrm{m}^{-2} \mathrm{~s}^{-1}\right)$, while the lowest for T2 $\left(1.58 \pm 0.25 \mathrm{mmol} \mathrm{m}^{-2} \mathrm{~s}^{-1}\right)$. Genotypes T5 $\left(3.05 \pm 0.05 \mathrm{mmol} \mathrm{m}^{-2} \mathrm{~s}^{-1}\right), \mathrm{T} 6\left(2.47 \pm 0.04 \mathrm{mmol} \mathrm{m}^{-2} \mathrm{~s}^{-1}\right), \mathrm{T} 4\left(2.12 \pm 0.01 \mathrm{mmol} \mathrm{m}^{-2} \mathrm{~s}^{-}\right.$ $\left.{ }^{1}\right), \mathrm{T} 1\left(2.03 \pm 0.05 \mathrm{mmol} \mathrm{m}^{-2} \mathrm{~s}^{-1}\right)$, and T7 $\left(1.87 \pm 0.04 \mathrm{mmol} \mathrm{m}^{-2} \mathrm{~s}^{-1}\right)$ were ranked in descending order into different homogenous groups (Figure $3 b$ ). The highest value of $g_{s}$ was observed for genotype T3 (158.6 $\left.\pm 0.55 \mathrm{mmol} \mathrm{m}^{-2} \mathrm{~s}^{-1}\right)$, while the lowest was recorded for genotype T2 (40.4 $\pm 0.89 \mathrm{mmol}$ $\left.\mathrm{m}^{-2} \mathrm{~s}^{-1}\right)$. T1 $\left(63.8 \pm 1.79 \mathrm{mmol} \mathrm{m}^{-2} \mathrm{~s}^{-1}\right)$ and $\mathrm{T} 4\left(63.8 \pm 0.45 \mathrm{mmol} \mathrm{m}^{-2} \mathrm{~s}^{-1}\right)$ genotypes did not differ in terms of $\mathrm{g}_{\mathrm{s}}$ (Figure $3 \mathrm{c}$ ). $\mathrm{C}_{\mathrm{i}}$ had the highest values in genotype T3 $\left(158.6 \pm 2.99 \mu \mathrm{mol} \mathrm{mol}^{-1}\right)$, while T2 $\left(46.5 \pm 2.31 \mu \mathrm{mol} \mathrm{mol}{ }^{-1}\right)$ genotype had the lowest value. Genotypes T1 (352 $\pm 0.89 \mu \mathrm{mol} \mathrm{mol}^{-}$ $\left.{ }^{1}\right)$, T4 $\left(327 \pm 2.38 \mu \mathrm{mol} \mathrm{mol}^{-1}\right)$, T5 $\left(365 \pm 1.26 \mu \mathrm{mol} \mathrm{mol}^{-1}\right), \mathrm{T} 6\left(374 \pm 2.08 \mu \mathrm{mol} \mathrm{mol}^{-1}\right)$, and T7 (295 $\pm 3.56 \mu \mathrm{mol} \mathrm{mol}^{-1}$ ) were ranked in descending order into different homogenous groups (Figure $3 d)$. 

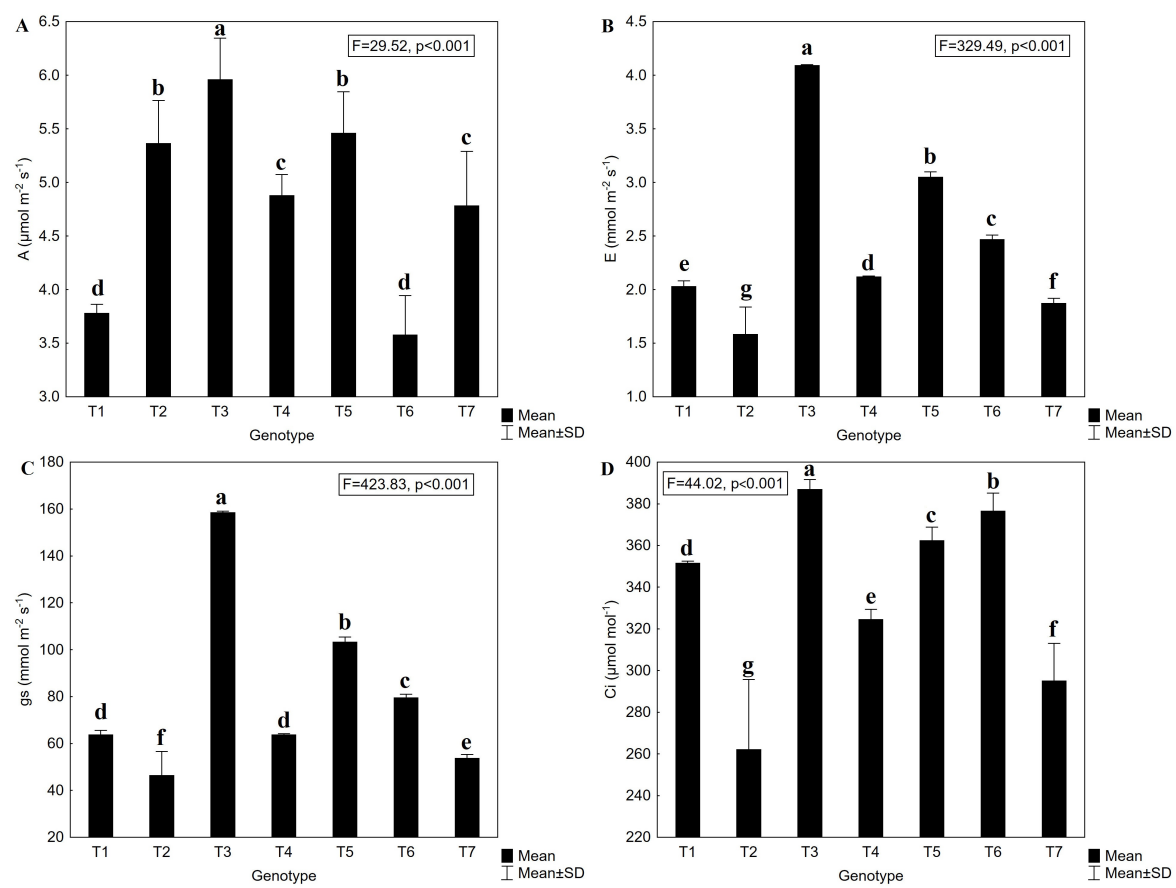

Figure 1. Leaf gas exchange parameters of seven silver linden (Tilia tomentosa Moench) genotypes. Net photosynthesis rate $\left(A\left[\mu \mathrm{mol} \mathrm{m}^{-2} \mathrm{~s}^{-1}\right]\right)$; rate of transpiration $\left(\mathrm{E}\left[\mathrm{mmol} \mathrm{m} \mathrm{m}^{-2} \mathrm{~s}^{-1}\right]\right)$; stomatal conductance $\left(\mathrm{g}_{\mathrm{s}}\left[\mathrm{mmol} \mathrm{m}^{-2} \mathrm{~s}^{-1}\right]\right)$; internal $\mathrm{CO}_{2}$ concertation $\left(\mathrm{C}_{\mathrm{i}}\left[\mu \mathrm{mol} \mathrm{mol}^{-1}\right]\right)$.

According to the correlation coefficients among the investigated parameters, a statistically significant positive correlation was observed between $\mathrm{g}_{\mathrm{s}}$ and $\mathrm{E}(\mathrm{r}=1.00, \mathrm{p}>0.05)$. Furthermore, a statistically significant negative correlation was detected between A and $\Psi_{\mathrm{md}}(\mathrm{r}=-0.78 ; \mathrm{p}>0.05)$.

Table 1. Correlation coefficients between physiological parameters.

\begin{tabular}{ccccc}
\hline & $\mathrm{g}_{\mathrm{s}}$ & $\mathrm{A}$ & $\mathrm{E}$ & $\Psi_{\mathrm{md}}$ \\
\hline $\mathrm{A}$ & 0.51 & - & & \\
$\mathrm{E}$ & $\mathbf{1 . 0 0}$ & 0.49 & - & - \\
$\Psi_{\mathrm{md}}$ & -0.04 & $\mathbf{- 0 . 7 8}$ & -0.04 & 0.46 \\
$\mathrm{C}_{\mathrm{i}}$ & -0.04 & -0.13 & 0.49 & \\
\hline
\end{tabular}

Legend: Net photosynthesis rate $\left(\mathrm{A}\left[\mu \mathrm{mol} \mathrm{m} \mathrm{m}^{-2} \mathrm{~s}^{-1}\right]\right)$; rate of transpiration $\left(\mathrm{E}\left[\mathrm{mmol} \mathrm{m} \mathrm{m}^{-2} \mathrm{~s}^{-1}\right]\right)$; stomatal conductance $\left(\mathrm{g}_{\mathrm{s}}\left[\mathrm{mmol} \mathrm{m}^{-2} \mathrm{~s}^{-1}\right]\right)$; intercellular $\mathrm{CO}_{2}$ concentration ( $\left.\mathrm{Ci}\left[\mu \mathrm{mol} \mathrm{mol}^{-1}\right]\right)$; midday leaf water potential ( $\left.\Psi_{\mathrm{md}}[\mathrm{MPa}]\right)$. Bolded numbers show correlation coefficients which are significant $(\mathrm{p}>0.05)$.

\section{Discussion}

Urban trees are affected by climatic change over time (Sjöman et al., 2018). In order to become more resilient to threats from pathogens, damages of insects and the effects of changing climate, it is essential for urban forests to possess high diversity - at different levels (species, 
genus, and family level) (Sjöman et al. 2018). At the species level, the most important task is to address the most successful genotype for urban environments. Regarding the suitability of species for urban settlements, lindens were racon to possess many advantages such as: good shade casting capacity, flowers with sensational smell and high ornamental values, which are ideally suited to cityscapes (Pawlikowski et al. 2010).

According to the results of leaf gas exchange parameters, it is possible to identify a genotype that has the best physiological performance and which is assumed to perform better under the predicted climate changes in comparison to other genotypes. However, in the case of $\Psi\left(\Psi_{\mathrm{pd}}\right.$ and $\left.\Psi_{\mathrm{md}}\right)$ we found statistically significant differences among the observed genotypes. According to Sjöman et al. (2018), species with $\Psi$ around -2.0 MPa respectively are considered to be highly sensitive to drought. Bearing in mind the result of $\Psi_{\mathrm{pd}}$ and $\Psi_{\mathrm{md}}(0.9-1.9 \mathrm{MPa})$ of the present study, we can conclude that the observed genotypes belong to the above-mentioned group. Similarly to this finding, Zhang et al. (2019) noted that T. cordata Greenspire cultivar appeared to be susceptible to drought in the urban environmental. Moreover, the poor growth of Tilia-road side trees in urban area of Poland were attributed to the lesser ability of this genus to cope with side environments (Swoczyna et al. 2014)

Assessment of $\Psi_{\mathrm{pd}}$ and $\Psi_{\mathrm{md}}$ can provide valuable information that resolves which genotype and species can maintain physiological function more effectively in stress conditions (Lenz et al. 2006), and have the capacity to adapt to environmental change (Sjöman et al. 2018). Observing the values of $\Psi_{\mathrm{pd}}$ and $\Psi_{\mathrm{md}}$ of the present stud, the highest values were detected for T3 genotype in comparison to the other six studied genotypes, suggesting its better performance. This was further supported as the same genotype exhibited the highest values of all leaf gas exchange parameters, namely, A, E, gs, and Ci.

The present study evidenced high genotypic variation in all investigated leaf gas exchange parameters. Variation in A can lead to variation in growth rate and productivity, which are important factors in terms of species competition and yield (Flood et al. 2011). Genotypic variation in the A response could result from the differences in stomatal responses or the activation of the carboxylation process (Soleh et al. 2016). Coupel-Ledru et al. (2014) found that E was not only controlled by water deficit but is also under the influence of genetic. Furthermore, environmental factors, such as, temperature, wind, light, soil water, and relative humidity can also affect the process of transpiration (Taiz and Zeiger, 2002). Variation in $g_{s}$ can result from different levels of water deficit, high temperature (Damour et al. 2010), and high urban $\mathrm{CO}_{2}$ concentrations (Ziska et al. 2004), and can influence the A. Higher $\mathrm{CO}_{2}$ concentrations might have relieved higher rates of A by urban trees, which would reduce water loss via stomatal conductance (Lahr et al. 2018).

Stomatal conductance $\left(g_{s}\right)$ is influenced by the morphological and structural traits and the opening of stomata (Galmes et al. 2013), as well. Our results confirmed the relationship between $\mathrm{g}_{\mathrm{s}}$ and $\mathrm{E}$ (Table 1), and this is not surprising given that $\mathrm{g}_{\mathrm{s}}$ directly controls the transpirational water flow from leaf to the ambient air. The slow decrease of $g_{s}$ will not affect $E$, but if $g_{s}$ decrease strongly then it would be beneficial for increasing E (Ouyang et al. 2017). $\Psi_{\mathrm{m}}$ was negatively correlated to A (Table 1). Similarly to our findings, Giorio et al. (1999) and Zufferey et al. (2000) reported that low $\Psi_{\text {md }}$ was coupled with low A values.

\section{Conclusion}

The results of the present study evidenced significant genotypic variation regarding all observed parameters of leaf gas exchange, namely $\mathrm{A}, \mathrm{E}, \mathrm{gs} \mathrm{Ci}, \Psi_{\mathrm{pd}}$, and $\Psi_{\mathrm{md}}$. The results of oneway analysis of variance noted high detrimental values of $g_{s}, A, E$, and $C_{i}$ for $T 3$ genotype compared to other observed genotypes. However, in terms of $\Psi_{\mathrm{md}}$ and $\Psi_{\mathrm{pd}}$ statistically significant genotypic variation was found in T5 and T3 genotypes. This study shows that physiological performance can be used in the selection of Silver linden genotypes. Namely, 
under the predicted climate changes the selection of tolerant genotypes is of crucial importance in order to enhance the resilience of urban forests. Evaluation of the leaf water potential and leaf gas exchange parameters gives strong evidence for a genotype variation under urban environment.

\section{Acknowledgments}

This study was financed by the Ministry of Education, Science and Technological Development of the Republic of Serbia (Project No: 451-03-68/2020-14/200197).

\section{References}

1. Aničić, M., Spasić, T., Tomašević, M., Rajšić, S., Tasić, M. (2011): Trace elements accumulation and temporal trends in leaves of urban deciduous trees (Aesculus hippocastanum and Tilia spp.). Ecological Indicators 11(3): 824-830.

2. Bahrun, A., Jensen, C.R., Asch, F., Mogensen, V.O. (2002): Drought-induced changes in xylem $\mathrm{pH}$, ionic composition, and ABA concentration act as early signals in field-grown maize (Zea mays L.). Journal of Experimental Botany 53: 251-263.

3. Bhatt, R.K. (1990): Seasonal variation in light absorption and transpiration in Prunus, Celtis and Grewia. Indian Journal of Forestry 13: 118-121.

4. Blackman, C.J., Brodribb, T.J., Jordan, G.J. (2010): Leaf hydraulic vulnerability is related to conduit dimensions and drought resistance across a diverse range of woody angiosperms. New Phytologist 188: 1113-1123.

5. Coupel-Ledru, A., Lebon, É., Christophe, A., Doligez, A., Cabrera-Bosquet, L., Péchier, P., Simonneau, T. (2014): Genetic variation in a grapevine progeny (Vitis vinifera $\mathrm{L}$. cvs Grenachex Syrah) reveals inconsistencies between maintenance of daytime leaf water potential and response of transpiration rate under drought. Journal of Experimental Botany 65: 6205-6218.

6. Damour, G., Simonneau, T., Cochard, H., Urban, L. (2010): An overview of models of stomatal conductance at the leaf level. Plant, Cell and Environment 33(9): 1419-1438.

7. Day, M.E., Greenwood, M.S., Diaz-Sala, C. (2002): Age-and size-related trends in woody plant shoot development: regulatory pathways and evidence for genetic control. Tree Physiology 22(8): 507-513.

8. De Souza, A.P., Gaspar, M., Da Silva, E.A., Ulian, E.C., Waclawovsky, A. J., Nishiyama Jr, M. Y., Buckeridge, M. S. (2008): Elevated CO2 increases photosynthesis, biomass and productivity, and modifies gene expression in sugarcane. Plant, Cell and Environment 31(8): 1116-1127.

9. Filiz, E., Birbilener, S., Ozyigit, I.I., Kulac, S., Sakinoglu Oruc, F.C. (2015): Assessment of genetic variations of silver lime (Tilia tomentosa Moench.) by RAPD markers in urban and forest ecosystems. Biotechnology and Biotechnological Equipment 29: 631-636.

10. Fini, A., Ferrini, F., Frangi, P., Amoroso, G., Piatti, R. (2009): Withholding irrigation during the establishment phase affected growth and physiology of Norway maple (Acer platanoides) and linden (Tilia spp.). Journal of Arboriculture 35(5): 241.

11. Flood, P.J., Harbinson, J., Aarts, M.G. (2011): Natural genetic variation in plant photosynthesis. Trends in Plant Science 16: 327-335.

12. Galmes, J., Ochogavia, J.M., Gago, J., Roldan, E.J., Cifre, J., Conesa, M.À. (2013): Leaf responses to drought stress in Mediterranean accessions of Solanum lycopersicum: anatomical adaptations in relation to gas exchange parameters. Plant, Cell and Environment 36(5): 920-935.

13. Gaosegelwe, P.L., Kirkham, M.B. (1990): Evaluation of wild, primitive, and adapted sorghums for drought resistance. In: Unger, P.W., Sneed, T.V., Jordan, W.R., Jensen, R.W. 
(eds). Challenges in Dryland Agriculture. A Global Perspective. Amarillo/Bushland, TX, US. pp. 224-226.

14. Gillner, S., Korn, S., Hofmann, M., Roloff, A. (2017): Contrasting strategies for tree species to cope with heat and dry conditions at urban sites. Urban Ecosystems 20(4): 853865.

15. Giorio, P., Sorrentino, G., d'Andria, R. (1999): Stomatal behaviour, leaf water status and photosynthetic response in field-grown olive trees under water deficit. Environmental and Experimental Botany 42(2): 95-104.

16. Herrick, JD., Thomas, R.B. (1999): Effects of $\mathrm{CO}_{2}$ enrichment on the photosynthetic light response of sun and shade leaves of canopy sweetgum trees (Liquidambar styraciflua) in a forest ecosystem. Tree Physiology 19(12): 779-786.

17. Iandolino, A. (2004): Canopy C balance and abiotic stress effects on the metabolic profile of flavonoids in grapevine (Vitis vinifera L.) berries. Doctoral Thesis. University of California, Davis.

18. Jackson, P., Basnayake, J., Inman-Bamber, G., Lakshmanan, P., Natarajan, S., Stokes, C. (2015): Genetic variation in transpiration efficiency and relationships between whole plant and leaf gas exchange measurements in Saccharum spp. and related germplasm. Journal of Experimental Botany 67: 861-871.

19. Klein, T. (2014): The variability of stomatal sensitivity to leaf water potential across tree species indicates a continuum between isohydric and anisohydric behaviours. Functional Ecology 28: 1313-1320.

20. Kostić, S., Levanič, T., Orlović, S., Matović, B., Stojanović, D.B. (2019): Pedunculate and turkey oaks radial increment and stable carbon isotope response to climate conditions through time. Topola/Poplar (204): 29-35.

21. Lahr, E.C., Dunn, R.R., Frank, S.D. (2018): Variation in photosynthesis and stomatal conductance among red maple (Acer rubrum) urban planted cultivars and wildtype trees in the southeastern United States. PloS ONE 13(5): e0197866.

22. Lenz, T.I., Wright, I.J., Westoby, M. (2006): Interrelations among pressure-volume curve traits across species and water availability gradients. Physiologia Plantarum 127(3): 423433.

23. Li, Y., Song, X., Li, S., Salter, W.T., Barbour, M.M. (2020): The role of leaf water potential in the temperature response of mesophyll conductance. New Phytologist 225(3): 11931205.

24. Lindner, M., Maroschek, M., Netherer, S., Kremer, A., Barbati, A., Garcia-Gonzalo, J., Lexer, M.J. (2010): Climate change impacts, adaptive capacity, and vulnerability of European forest ecosystems. Forest ecology and management 259(4): 698-709.

25. Lintunen, A., Paljakka, T., Salmon, Y., Dewar, R., Riikonen, A., Hölttä, T. (2019): The influence of soil temperature and water content on belowground hydraulic conductance and leaf gas exchange in mature trees of three boreal species. Plant, Cell and Environment 43(3): 532-547.

26. Mauer, W.D., Tabel, U. (1995): A methodological study to improve the isozyme analysis for identification of clones of Tilia (Linden syn. Lime Tree). Silvae Genetica 45: 351-356.

27. Mencuccini, M. (2003): The ecological significance of long-distance water transport: short-term regulation, long-term acclimation and the hydraulic costs of stature across plant life forms. Plant, Cell and Environment 26: 163-182.

28. Mitchell, P.J., Veneklaas, E.J., Lambers, H., Burgess. S.S.O. (2008): Leaf water relations during summer water deficit: differential responses in turgor maintenance and variations in leaf structure among different plant communities in southwestern Australia. Plant, Cell and Environment 31: 1791-1802. 
29. Mozdzer, T.J., Zieman, J.C. (2010): Ecophysiological differencesbetween genetic lineages facilitate the invasion of non-native Phragmites australis in North American Atlantic coast wetlands. Journal of Ecology 98: 451-458.

30. Oren, R., Zimmerman, R. Terborgh, J. (1996): Transpiration in upper Amazonia flood plain and upland forests in response to drought breaking rains. Ecology 77: 968-973.

31. Ouyang, W., Struik, P. C., Yin, X., Yang, J. (2017): Stomatal conductance, mesophyll conductance, and transpiration efficiency in relation to leaf anatomy in rice and wheat genotypes under drought. Journal of Experimental Botany 68(18): 5191-5205.

32. Pawlikowski,T. (2010): Pollination activity of bees (Apoidea: Apiformes) visiting the flowers of Tilia cordata Mill. and Tilia tomentosa Moench in an urban environment. Journal of Apicultural Science 54(2): 73-79.

33. Possen, B.J., Anttonen, M.J., Oksanen, E., Rousi, M., Heinonen, J., Kostiainen, K., Vapaavuori, E.M. (2014): Variation in 13 leaf morphological and physiological traits within a silver birch (Betula pendula) stand and their relation to growth. Canadian Journal of Forest Research 44: 657-665.

34. Reddy, P.S. (2019): Breeding for abiotic stress resistance in Sorghum. In: Aruna, C., Visarada, K.B.R.S.., Bhat, V.B., Tonapi, V.A. (eds.). Breeding Sorghum for diverse end uses. Woodhead Publishing. pp. 325-340.

35. Roth, B.E., Jokela, E.J., Martin, T.A., Huber, D.A., White, T.L. (2007): Genotype $\times$ environment interactions in selected loblolly and slash pine plantations in the Southeastern United States. Forest Ecology and Management 238: 175-188.

36. Rushforth, K. (1999): Trees of Britain and Europe. HarperCollins, London, UK.

37. Silim, S., Nash, R., Reynard, D., White, B., Schroeder, W. (2009): Leaf gas exchange and water potential responses to drought in nine poplar (Populus spp.) clones with contrasting drought tolerance. Trees 23(5): 959-969.

38. Šircelj, H., Tausz, M., Grill, D., Batič, F. (2007): Detecting different levels of drought stress in apple trees (Malus domestica Borkh.) with selected biochemical and physiological parameters. Scientia Horticulturae 113: 362-369.

39. Sjöman, H., Hirons, A.D., Bassuk, N.L. (2018): Improving confidence in tree species selection for challenging urban sites: a role for leaf turgor loss. Urban Ecosystems 21(6): 1171-1188.

40. Soleh, M.A., Tanaka, Y., Nomoto, Y., Iwahashi, Y., Nakashima, K., Fukuda, Y., Shiraiwa, T. (2016): Factors underlying genotypic differences in the induction of photosynthesis in soybean [Glycine $\max$ (L.) Merr.]. Plant, Cell and Environment 39: 685-693.

41. Swoczyna, T., Borowski, J., Pietkiewicz, S., Kalaji, H.M. (2014): Growth and physiological performance of young urban trees of eight taxa in Warsaw. Plants in Urban Areas and Landscape: $15-19$.

42. Taiz, L., Zeiger, E. (2002): Photosynthesis: physiological and ecological considerations. Plant Physiologist 9: 172-174.

43. Tissue, D.T., Griffin, K.L., Turnbull, M.H., Whitehead D. (2001): Canopy position and needle age affect photosynthetic response in field-grown Pinus radiata after five years of exposure to elevated carbon dioxide partial pressure. Tree Physiology 21(12-13): 915-923.

44. Tyree, M.T. (1997): The cohesion-tension theory of sap ascent: current controversies. Journal of Experimental Botany 48: 1753-1765.

45. Van Rooijen, R., Aarts, M.G., Harbinson, J. (2015): Natural genetic variation for acclimation of photosynthetic light use efficiency to growth irradiance in Arabidopsis. Plant Physiology 167: 1412-1429.

46. Vaštag, E., Orlović, S. S., Ljubojević, M., Čukanović, J., Pavlović, L., Vestek, A., Bojović, M. (2018): Diversity of dendroflora of one of the urban blocks in the Novo Naselje district of Novi Sad. Topola/Poplar 201-202: 33-43. 
47. Vastag, E., Kesić, L., Karaklić, V., Zorić, M., Vuksanović, V., Stojnić, S. (2019): Physiological performance of sweetgum (Liquidambar stryraciflua L.) and norway maple (Acer platanoides L.) under drought condition in urban environment. Topola/Poplar 204: 17-27.

48. Vastag E., Cocozza C., Orlović S., Kesić L., Kresoja M., Stojnić S. (2020): Half-sib lines of Pedunculate oak (Quercus robur L.) respond differently to drought through biometrical, anatomical and physiological traits. Forests 11: 153.

49. Williams, L.E., Dokoozlian, N.K., Wample, R. (1994): Grape. In: Shaffer, B., Anderson, P.C. (eds). Handbook of Environmental Physiology Fruit Crops. Temperate crops, I. CRC Press, Orlando, Florida: 85-133.

50. Zhang, C., Stratopoulos, L.M.F., Pretzsch, H., Rötzer, T. (2019): How do Tilia cordata greenspire trees cope with drought stress regarding their biomass allocation and ecosystem services? Forests 10(8): 676.

51. Ziska, L.H., Bunce, J.A., Goins, E.W. (2004): Characterization of an urban-rural $\mathrm{CO}_{2} /$ temperature gradient and associated changes in initial plant productivity during secondary succession. Oecologia 139(3): 454-458.

52. Zufferey, V., Murisier, F., Schultz, H.R. (2000): A model analysis of the photosynthetic response of Vitis vinifera L. cvs Riesling and Chasselas leaves in the field: I. Interaction of age, light and temperature. Vitid-Gelweilerhof 39: 19-26. 